\title{
WIPP Conceptual Design Report
}

Addendum I: Soils and Foundation Investigation for Proposed Waste Isolation Pilot Plant, Eddy County, New Mexico, By Richard R. Pettigrew and Associates, Consulting Engineers. 


\section{DISCLAIMER}

This report was prepared as an account of work sponsored by an agency of the United States Government. Neither the United States Government nor any agency Thereof, nor any of their employees, makes any warranty, express or implied, or assumes any legal liability or responsibility for the accuracy, completeness, or usefulness of any information, apparatus, product, or process disclosed, or represents that its use would not infringe privately owned rights. Reference herein to any specific commercial product, process, or service by trade name, trademark, manufacturer, or otherwise does not necessarily constitute or imply its endorsement, recommendation, or favoring by the United States Government or any agency thereof. The views and opinions of authors expressed herein do not necessarily state or reflect those of the United States Government or any agency thereof. 


\section{DISCLAIMER}

Portions of this document may be illegible in electronic image products. Images are produced from the best available original document. 
Issued by Sandia Laboratories, operated for the United States Energy Research \& Development Administration by Sandia Corporation.

\section{NOTICE}

This report was prepared as an account of work sponsored by the United States Government. Neither the United States nor the United States Energy Research \& Development Administration, nor any of their employees, nur dily of llieii contractors, subcontractors, or their employees, makes any warranty, express or implied, or assumes any legal liability or responsibility for the accuracy, completeness or usefulness of any infurmation, apparatus, product or process disclosed, or represents that its use would not infringe privately owned rights. 


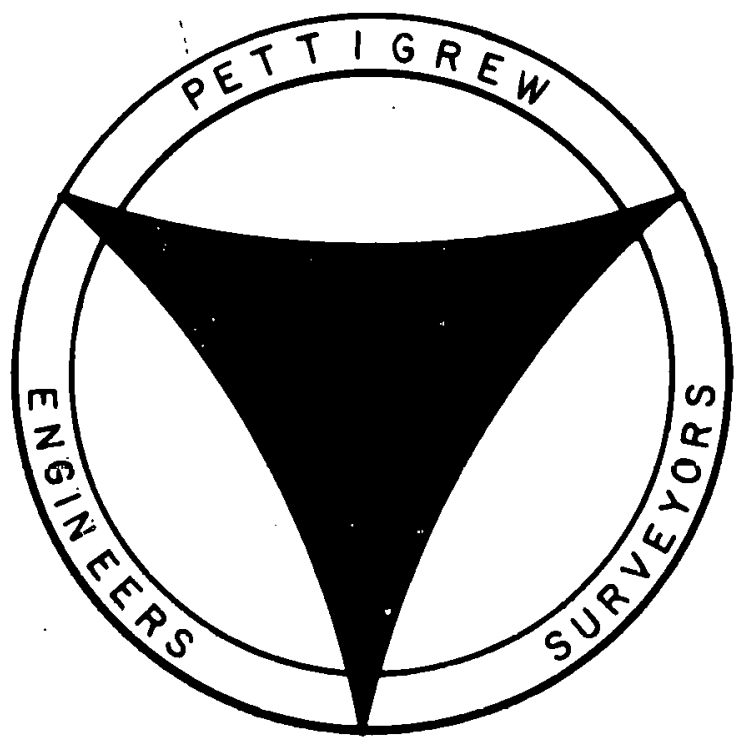

SOILS AND FOUNDATION

INVESTIGATION

FOR

PROPOSED

WASTE ISOLATION PILOT PLANT

EDDY COUNTY, NEW MEXICO

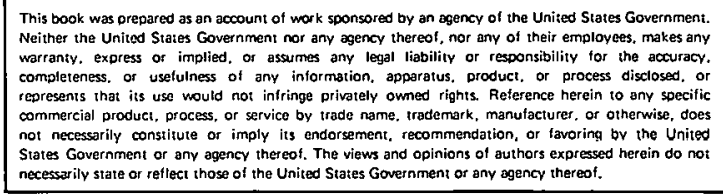

J RICHARD R. PETTIGREW

PREPARED FOR:

CONSULTING ENGINEERS

SANDIA LABORĀTORIES

POST OFFICE DRAWER 807 KIRTLAND AIR FORCE BASE EAST

613 INDUSTRIAL PARK

ALBUQUERQUE, NEW MEXICO

87115

$+$

(505) $762-3716$ 


\section{SOILS \& FOUNDATION}

INVESTIGATION

FOR

PROPOSED

WASTE ISOLATION PILOT PLANT

EDDY COUNTY, NEW MEXICO

PREPARED FOR:

JOHN WEST ENGINEERING COMPANY 412 No. Dal Paso

Hobbs, New Mexico 88240 .

FOR:

SANDIA LABORATORIES

KIRTLAND AIR FORCE BASE EAST

ALBUQUERQUE, NEW MEXICO 87115

LAB NO. $6 \mathrm{~L}-6263$

DATE: DECEMBER, 1976 


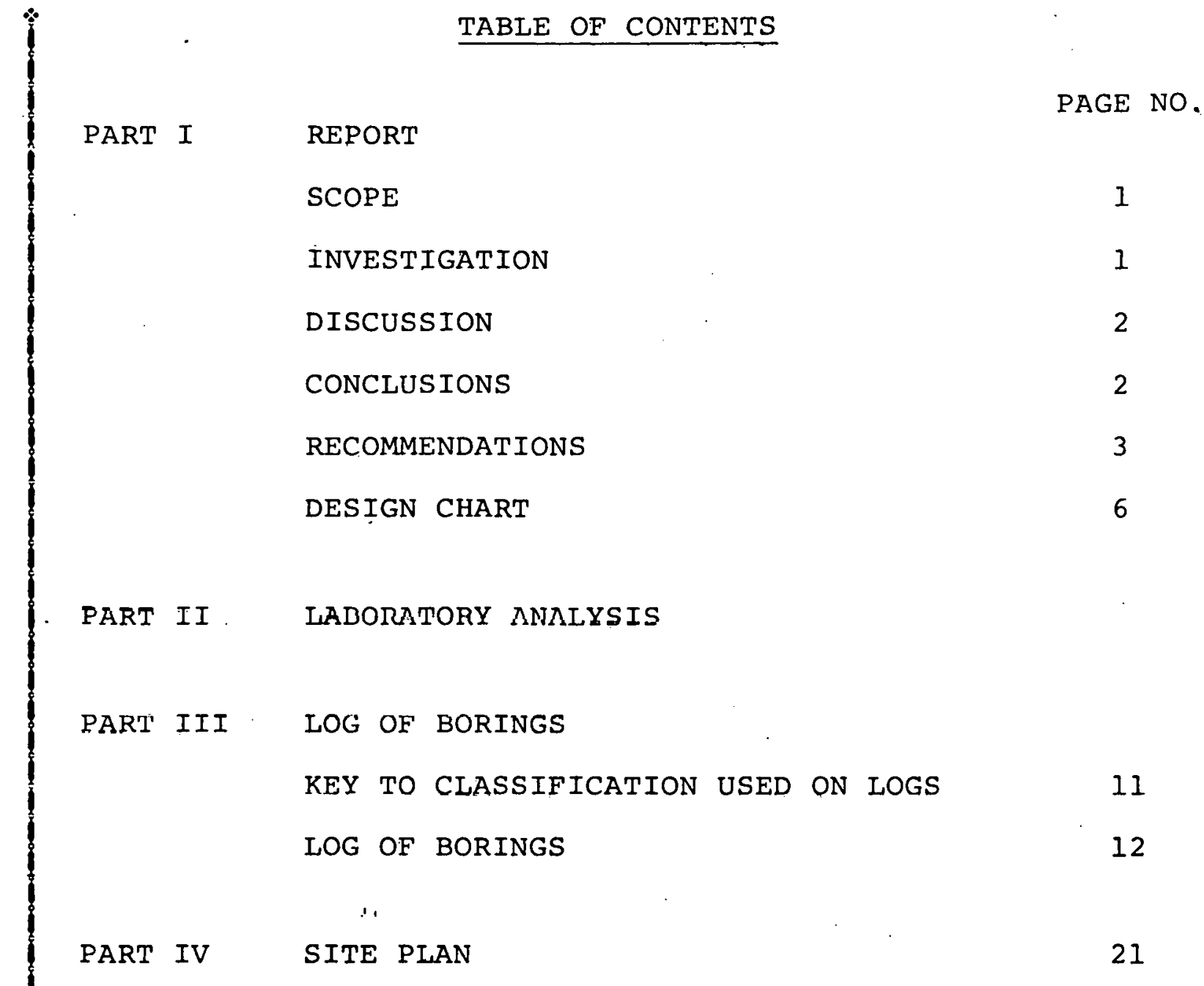




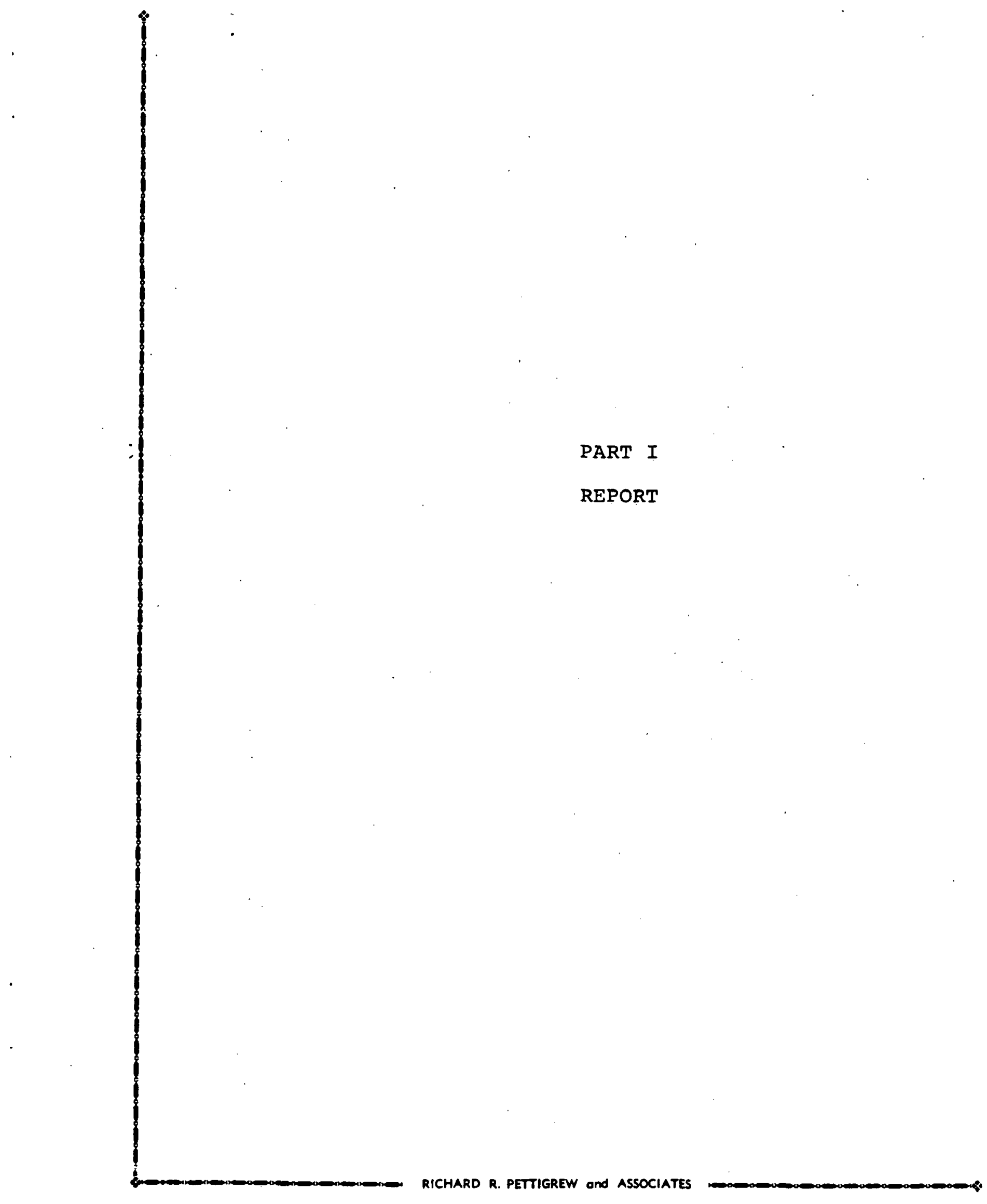




\section{SCOPE}

This Report presents the results of a Soils and Foundation investigation for the Proposed Waste Isolation Pilot Plant (WIPP) located in Section 21, Tównship 22 South, Range 31 East, N.M.P.M.A, Eddy County, New Mexico. The purpose of this investigation was to determine the physical characteristics of the subsoils in order to provide foundation design recommendations. The investigation was performed and the report prepared in accórdance with the requirements received from John west Engineering Company and Mr. Bill Wowak; Sandia Laboratories. These were:

1. Statement of work for WIPP soils Investigation Program, and

2. WIPP Soil Investigation revisèd drili hole location.

\section{INVESTIGATION}

Eight (8). test borings were made on the site under dates of November 16, 17, 18: 19, 1976. "The location of the test holes is presented:on the Site Plan (See Page "21 of this Report).

A rotary drill rig, using air, was employed to make the borings. During the test drilling, the soils encountered were: continuously examined, visually classified, and where applicable, sampled:

Standard penetration tests were performed and cores were taken at varying depths as presented in the Log of Borings. Penetration resistance was measured by driving a standard 2 inch splittube sampler having a 30 inch free-fall drop hammer weighing 140 pounds. Cores were taken utilizing a l inch inside diameter diamond core bit. The cores were removed from the sampler in the field, logged, and sealed to maintain "in-situ" conditions, while, being transported to the Laboratory.

Mechanical analysis and soils constant determinations were made on the soils to establish classification and identification of each soil, type. 
Unconfined compression tests were performed on certain soils. A combination of the Field and Laboratory Tests were performed to determine both the bearing capacity and to give an indication of the swell and settlement. characteristics of the soils encountered.

\section{DISCUSSION}

'lhe proposed site is Iorater in range latrd with no visudd evidence of pl lor structures or doep oite disturbance wlich would influence the performance of the footings of the proposed construction.

The ground surface is very sandy and although the drill unit was able to negotiate the terrain, mobilization problems could occur.

Because of variations in the elevations of the subsoils an on-site determination was made to drill all eight test holes rather than the six sighted in the stiatement of work. A more: . accurate soil profile was the result of this decision.

No groundwater was encountered during the investigation.

Maximum frost line action in this locile is generally considered to be approximately 18 inches depending upon the soils. However, the sands encountered should be relatively "frost free".

Since neither the site grading plan or the proposed.

loadings on the foundations was available lo the Soils Engineers this Report by necessity can present only generalizations. The Structural Engineers must make the final determinaliun for type. ond depth of foundations.

\section{CONCIUSIONS}

Sight grading, structural locations, and foundation loadings are the governing factors in the site development. Generally, under embankments, the existing ground should be scarified, moistened and compacted to such a degree that the sands 
will present a uniform bearing capacity.

In moistened and compacted sands, excavation could probably be made to a maximum depth of $4^{\prime}$ without lateral support. Deeper excavation will require bracing or slopes laid back on a minumum of $1-1 / 2$ to 1 .

The surface sands encountered will provide excellent: 'on-site' building fill. If these sands are used for building' fill, a moisture barrier between the building fill and the concrete floor siabs on grade will not be required.

\section{RECOMMENDATIONS}

\section{T. Sit.e Development}

A. The natural sands under embankments should be scarified and compacted at approximately optinum moisture to a minimum of $90 \%$ and a maximum of $95 \%$ of Laboratory Densities as determined by ASTM D-698. The depth of this preparation will vary over the site area, but as a minimum should be to the depth where $N=20$, as presented in the Log of Borings.

B. Embankments - The sands utilized in embankments should be moistened and compacted to the relative density as described in No. I above.

c. A Prime Consideration of the Site Grading should be that the footings or foundations rest upon soils of comparable bearing value in order that excessive differential settlement cannot occur.

II Basis of Foundation Design

A. Conceivably, footings or foundations, can 
rest upon five distinct soil formations as follows:

1. Sand - Soil Classification - SM-SP, or

2. Sand Clay Mixtures - Soil Classification - SC, or,

3. Caliche - Soil Classification - SM Caliche is a formation consisting of calcium cartoonate and silica and a form of clays, sand and gravel cemented into a conglomerate by calcium carbonate, or,

4. Sandstone, or

5. Stratified Sandstone and Clay (consolidated).

B. Footings on sand

1. For vertical loads see Design Chart (page 6) of this Report

2. For lateral loads (unconsolidated materials)

a. In place unit weight of material $\gamma=$ 100 p.c.f.

b. Angle of internal friction $\phi=33^{\circ}$.

c. Total pressure per unit width $\mathrm{P}=1 / 2 \mathrm{~K} \gamma \mathrm{H}^{2}$ applied $2 / 3 \mathrm{H}$ below the ground-surface and inclined at. the angle of with the horizontal.

WHERE :

$$
\begin{aligned}
& \mathrm{H}=\text { depth of the bottom of footing } \\
& \text { below the groundline } \\
& \mathrm{K}=\text { the coefficient of earth pres- } \\
& \text { sure as follows: } \\
& \text { Active Pressure - } \mathrm{K}_{\mathrm{a}}=0.29 \\
& \quad \text { Passive Pressure- } \mathrm{K}_{\mathrm{p}}=3.39 \\
& \text { At Rest } \quad-\mathrm{K}_{\mathrm{O}}=0.45
\end{aligned}
$$

d. Friction factor to be used for footings, 


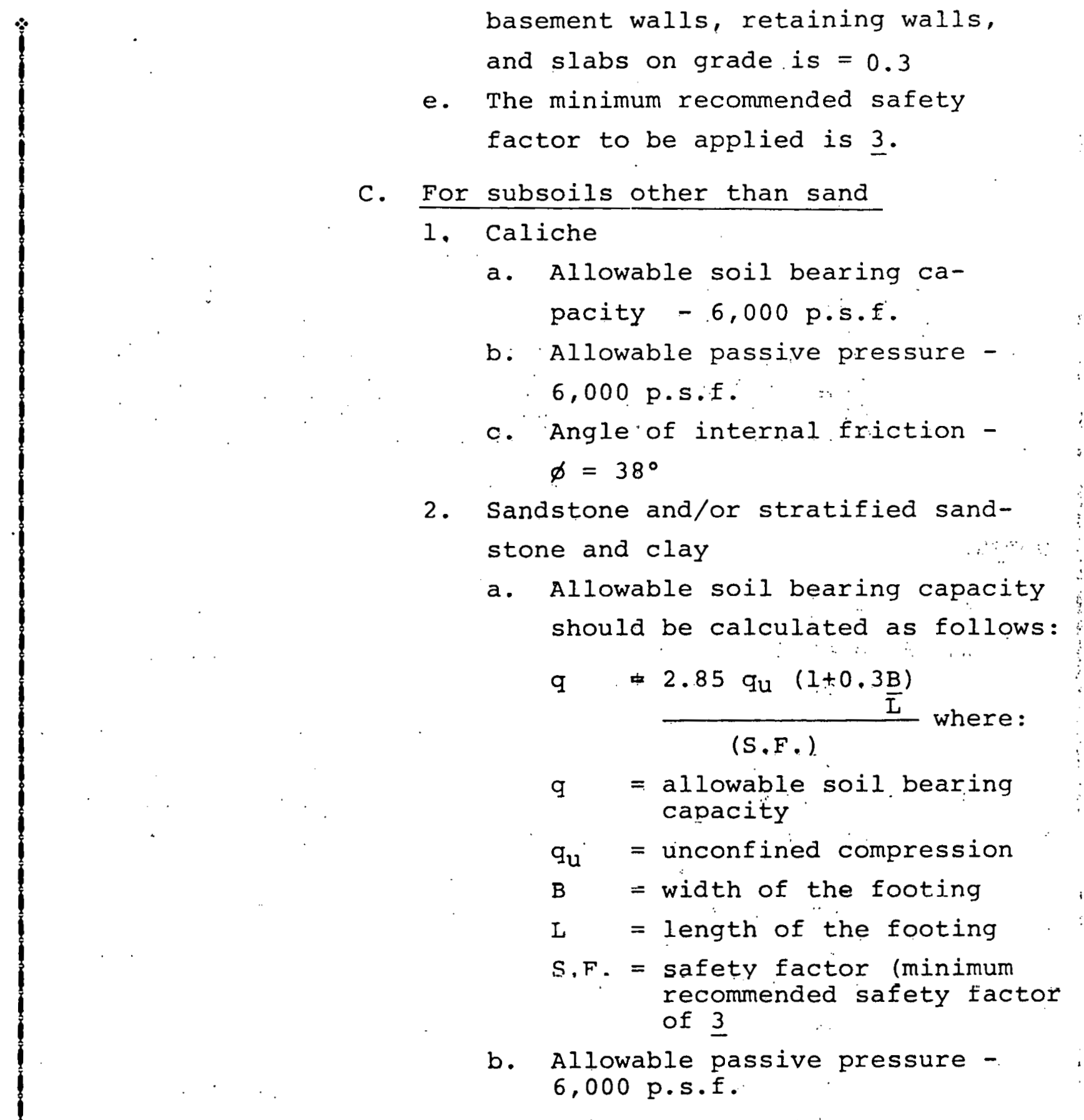




\section{DESIGN CHART FOR PROPORTIONING SHALLOW FOOTINGS ON SAND ${ }^{1}$}

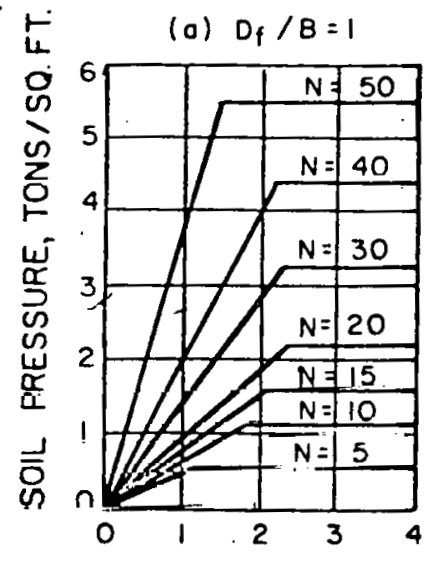

(b) $D_{f} / B=0.5$

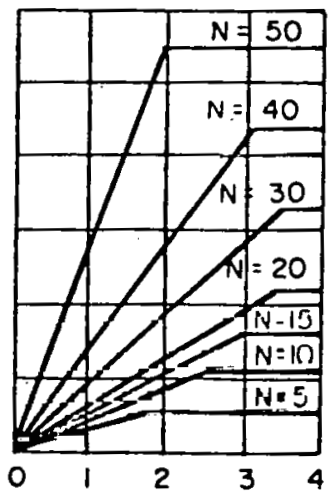

WIDTH OF FOOTINE, B, FT. (c) $D_{f} / B=0.25$

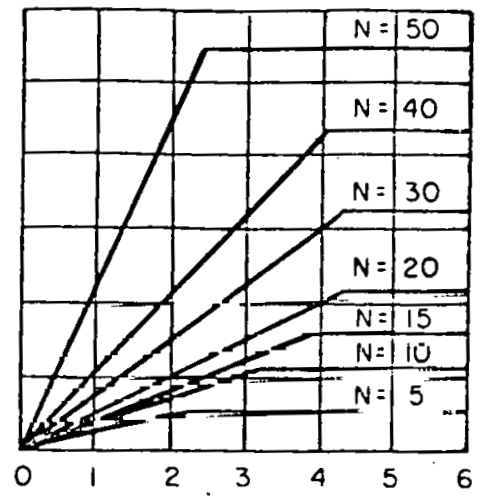

NOTES:

1: $D_{f}=$ the depth of footing below the ground surface

2. $\mathrm{B}=\mathrm{a}$ ) The width of a long, continuous footing, or

b). Side of a square footing, or

r) The emaller dimension of a rectangular footing, or

d) Diameter of a circular footing.

3. Uncorrected $\mathrm{N}$ values may be used at depths of 10-?5 feet, or when the effective overburden pressure is between 0.8 and 1.2 tons per sq. ft.

4. For conditions other than those presented above, a correction factor should be multiplied by the field $N$ values as follows:

$\mathrm{C}_{\mathrm{N}}=0.77 \log _{10} \frac{20}{\mathrm{p}}$, where $\mathrm{F}$ is the effuctive

vertical overburden pressure in tone por square

foot at the elevation of the pulltration tesl.

This equation is valid for $\bar{p} \overline{\bar{y}} 0.25$ tons per sq. ft.

If $\bar{p}<0.25$ tons per sq. ft. use $c_{N}=2.0$.

5. Charts are based upon a maximum settlement of $1^{\prime \prime}$.

5. Charts are based on unit weight of material aporoximately 100 pounds per cubic ft.

lFoundation Engineering, 2nd Edition, John Wiley \& Sons, Inc. 


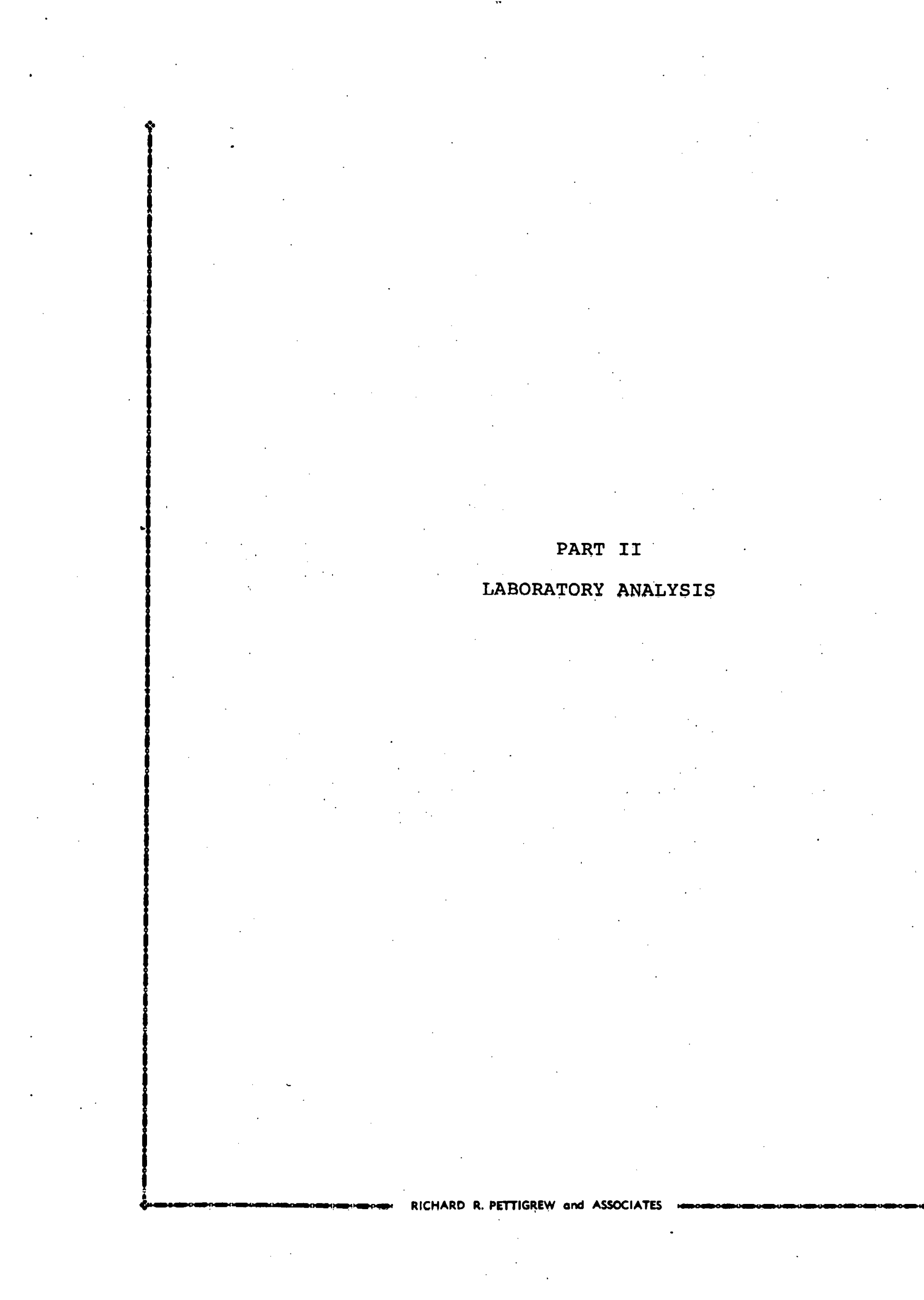




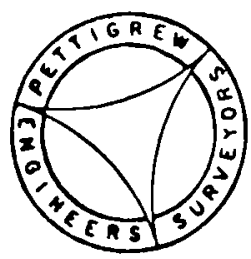

TO: SANDIA LAB

PROJECT: WASTE ISOLATION PILOT PLANT

DATE OF TEST: November, 1976

SEIVE SIZE

\#4

\#10

$\# 30$

$\# 40$.

$\# 60$

$\# 100$

$\# 200$

Sandy Non Plastic

Volumetric Shrinkage

SOIL CLASSIFICATION
TYPE OF TEST:

\section{SOIL ANAYLSIS \& CLASSIFICATION}

P. O. DRAWER BO7

Clovis, New MeXico 88101

505762.3716

\begin{tabular}{cc} 
COMBINED \\
HOLE NO. DEPTH REPRESENTED \\
1 & $0^{\prime \prime}-7^{\prime} 7^{\prime \prime}$ \\
2 & $0^{\prime}-2^{\prime}$ \\
3 & $0^{\prime}-5^{\prime} 9^{\prime \prime}$ \\
4 & $0^{\prime}-2^{\prime} 6^{\prime \prime}$ \\
& $\&$ \\
& $4^{\prime} 1^{\prime \prime}-6^{\prime} 6^{\prime \prime}$ \\
5 & $0^{\prime}-5^{\prime} 5^{\prime \prime}$ \\
6 & $0^{\prime}-1^{\prime} 9^{\prime \prime}$ \\
7 & $0^{\prime}-7^{\prime} 1^{\prime \prime}$ \\
8 & $0^{\prime}-4^{\prime} 6^{\prime \prime}$ \\
\hline
\end{tabular}

100

100

99.7

98.1

56.0

26.1

10.4

0 .

SM-SP - Silty Sands, Sandsilt Mixtures, Poorly Graded Sands, Gravelly Sands, little or no Fines

LAB. NO. - $-6 I-6263$

RICHARD R. PETTIGREW AND ASSOCIATES 
TO: SANDIA LAB

TYPE OF TEST:

SOIL ANAYLSIS \& CLASSIFICATION

PROJECT: WASTE ISOLATION PILOT PLANT

DATE of TEST: November, 1976

LAB. NO. $6 \mathrm{~L}-6263$

$1 / 2 "$
$1 "$
$1 / 2 "$
$\# 4$
$\# 10$
$\# 30$
$\# 40$
$\# 60$
$\# 1.00$
$\# 200$

Liquid Limit

Plastic Limil

Plasticity Index

Linedr Shrinkage

Shrinkage Limit

Shrinkage Ratio

Volumetric Shrinkage

Specific Gravity

GOIL CLAS'SIFICA'IION

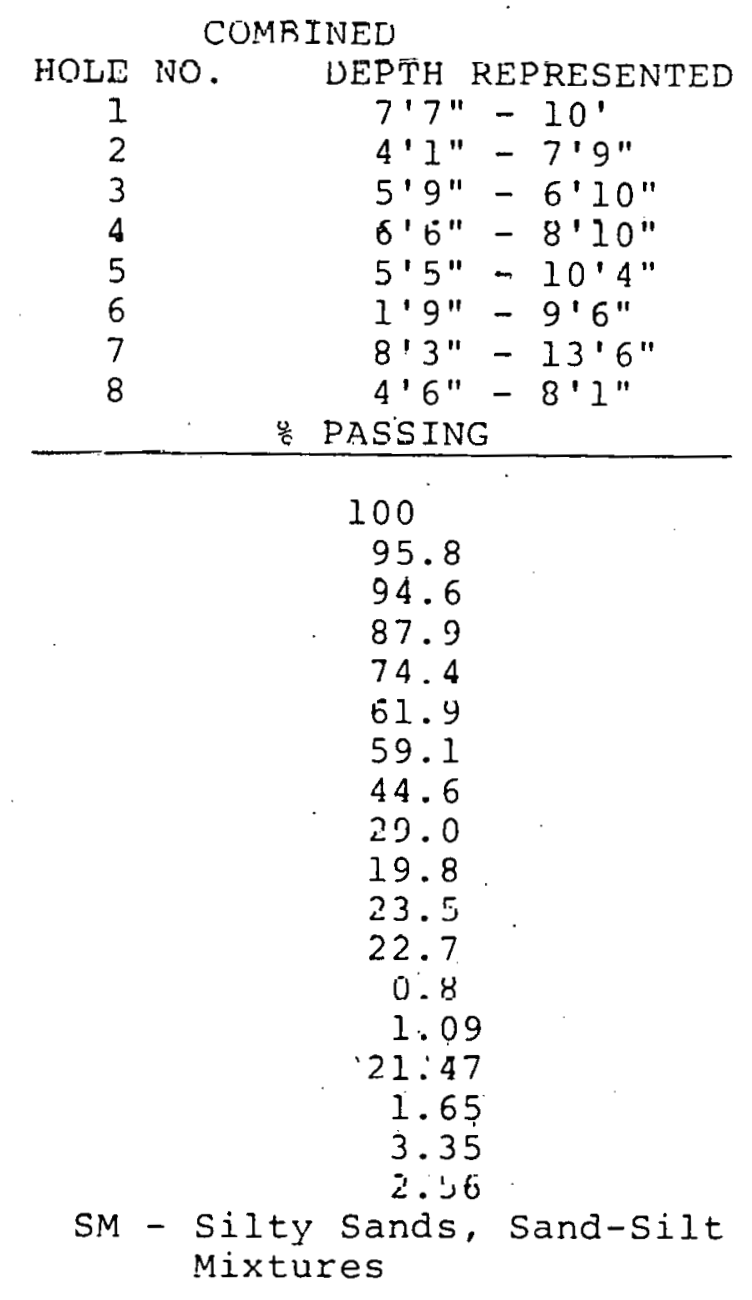

RICHARD R. PETTIGREW AND ASSOCIATES 


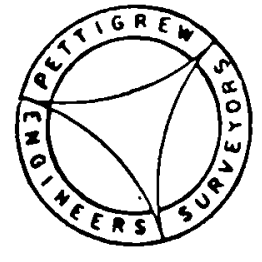

TO: SANDIA LAB

PROJECT: WASTE ISOLATION PILOT PLANT

RICHARD R. PETTIGREW AND ASSOCIATES

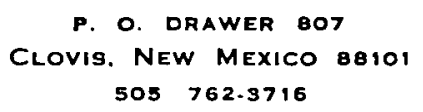

SOIL ANAYLSIS \& CLASSIFICATION

DATE OF TEST: NOvember, 1976

\section{SEIVE SIZE}

\# 4

$\# 10$

$\# 30$

$\# 40$

$\# 60$

$\# 100$

$\# 200$

Liquid Limit

Plastic Limit

Plasticity Index

Linear Shrinkage

Shrinkaye Lillil

Shrinkage Ratio

Volumetric Shrinkage

Specific Gravity

SOIL CLASSIFICATION

\begin{tabular}{rr} 
COMBINED \\
HOLE NO. DEPTH REPRESENTED \\
2 & $2{ }^{\prime}-4 ' 1 "$ \\
4 & $26^{\prime \prime}-4{ }^{\prime} 1 "$ \\
7 & $7 \cdot 1 "-8 \cdot 3 "$ \\
\hline
\end{tabular}

100

1.00

99.6

97.9

69.0

38.5

23.9

25.6

17.4

8.2

4.98

16.19

1.76

16.56

2.46

SC - Clayey Sands, SandClay Mixtures

LAB. NO. $\quad 6 L-6263$

RICHARD R. PETTIGREW AND ASSOCIATES 


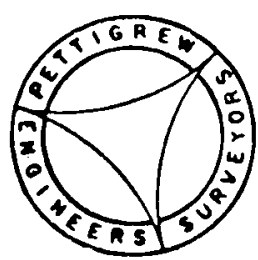

TO: SANDIA LAB

Project: WASTE ISOLATION PILOT PLANT

DATE OF TESI: Nnvember, 1976

SEIVE SIZE

$1 / 2^{\prime \prime}$

\#4

$\# 10$

\#30

\#40

\#60

\#100

\#200

Liquia LimiL

Plastic Limit

Plasticity Index

Linear Shrinkag̣e

shrinkage Iimit

Shrinkaqe Ratio

Volumetric Shrinkage

SOIL CLASSIFICATION

LAв. No. $6 I-6263$

\section{RICHARD R. PETTIGREW AND ASSOCIATES}

P. O. DRAWER 607

Clovis, NeW MEXICO OBIOI

505762.3716

SOIL ANAYLSIS \& CLASSIFICATION 


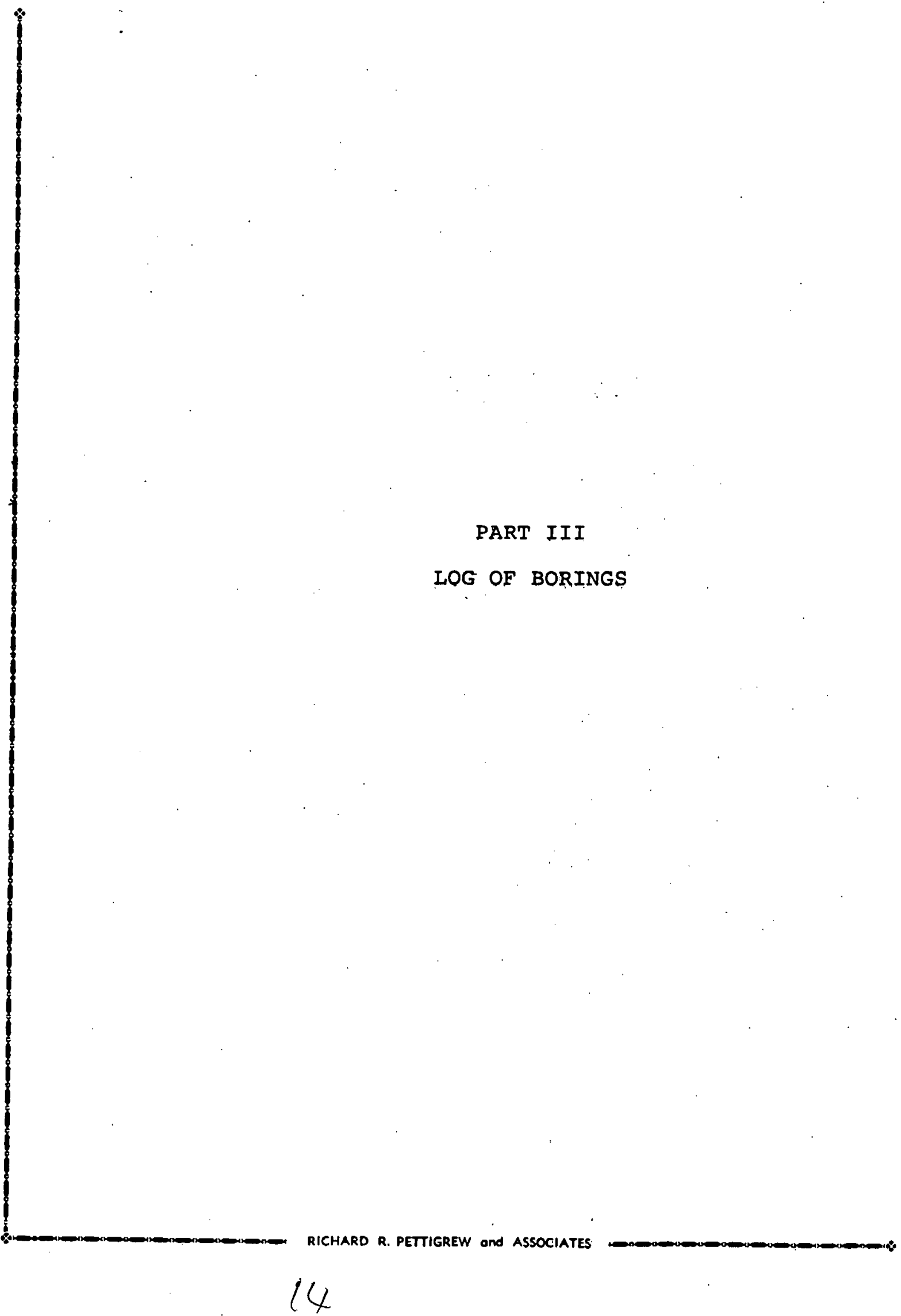




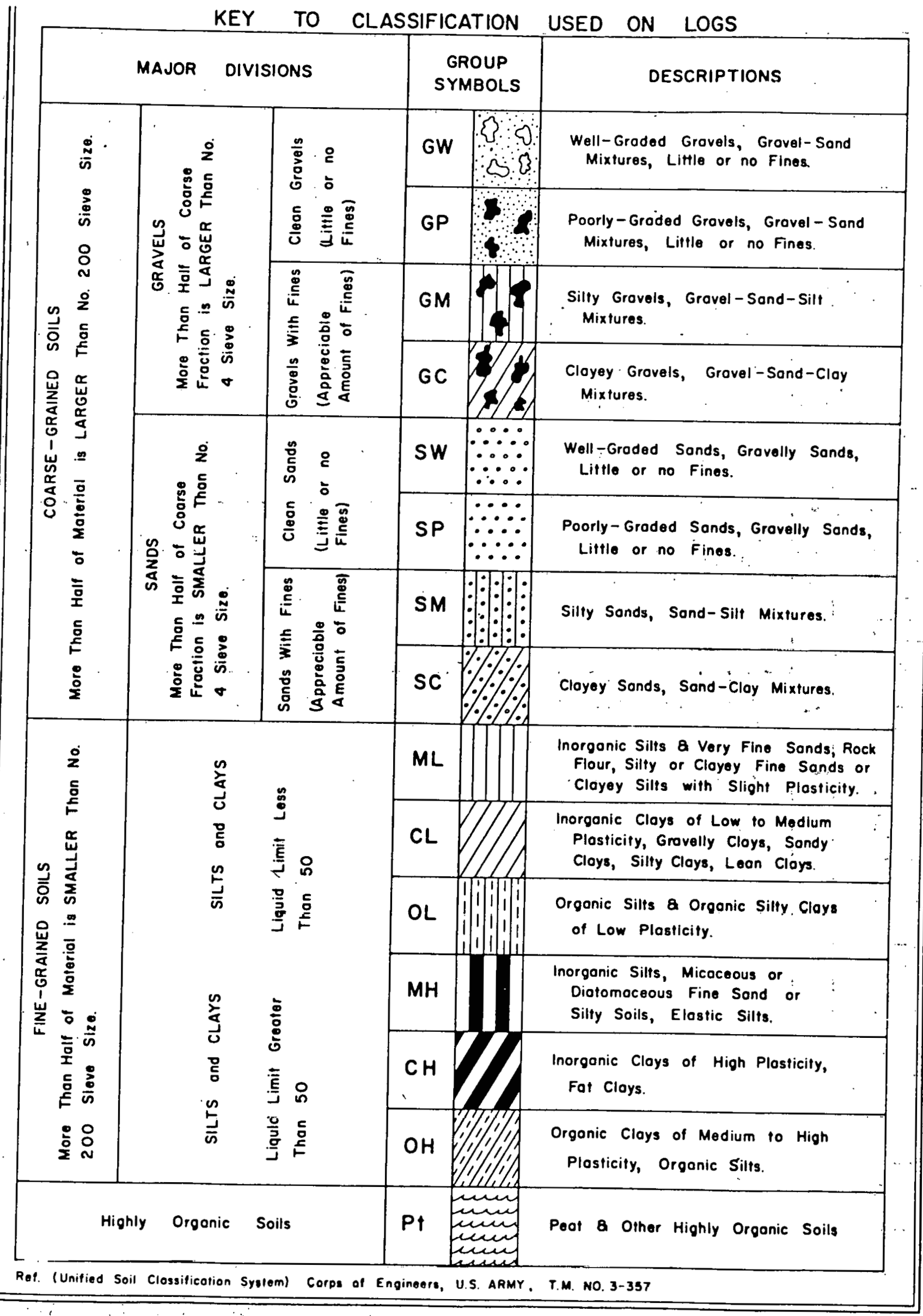




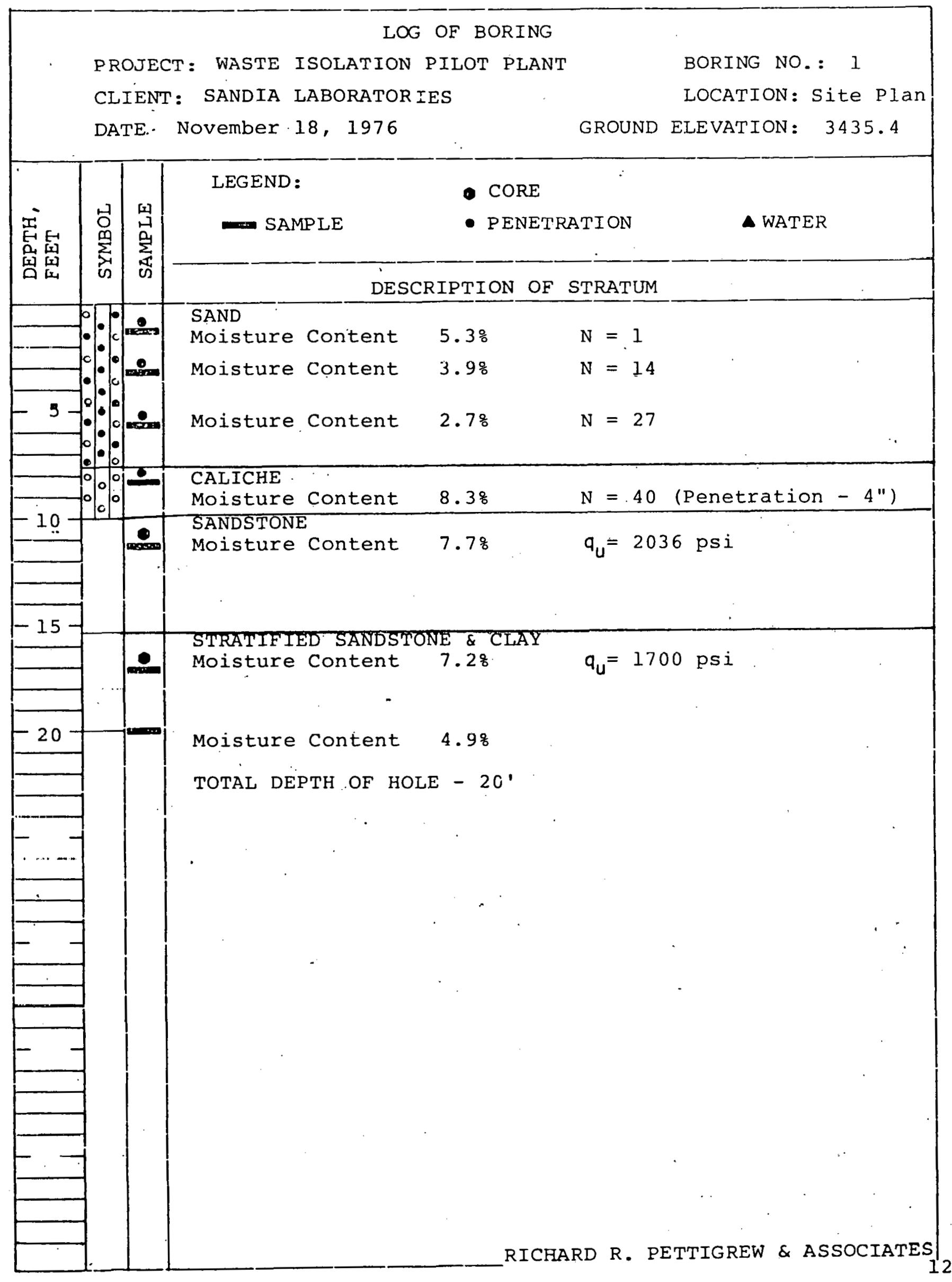




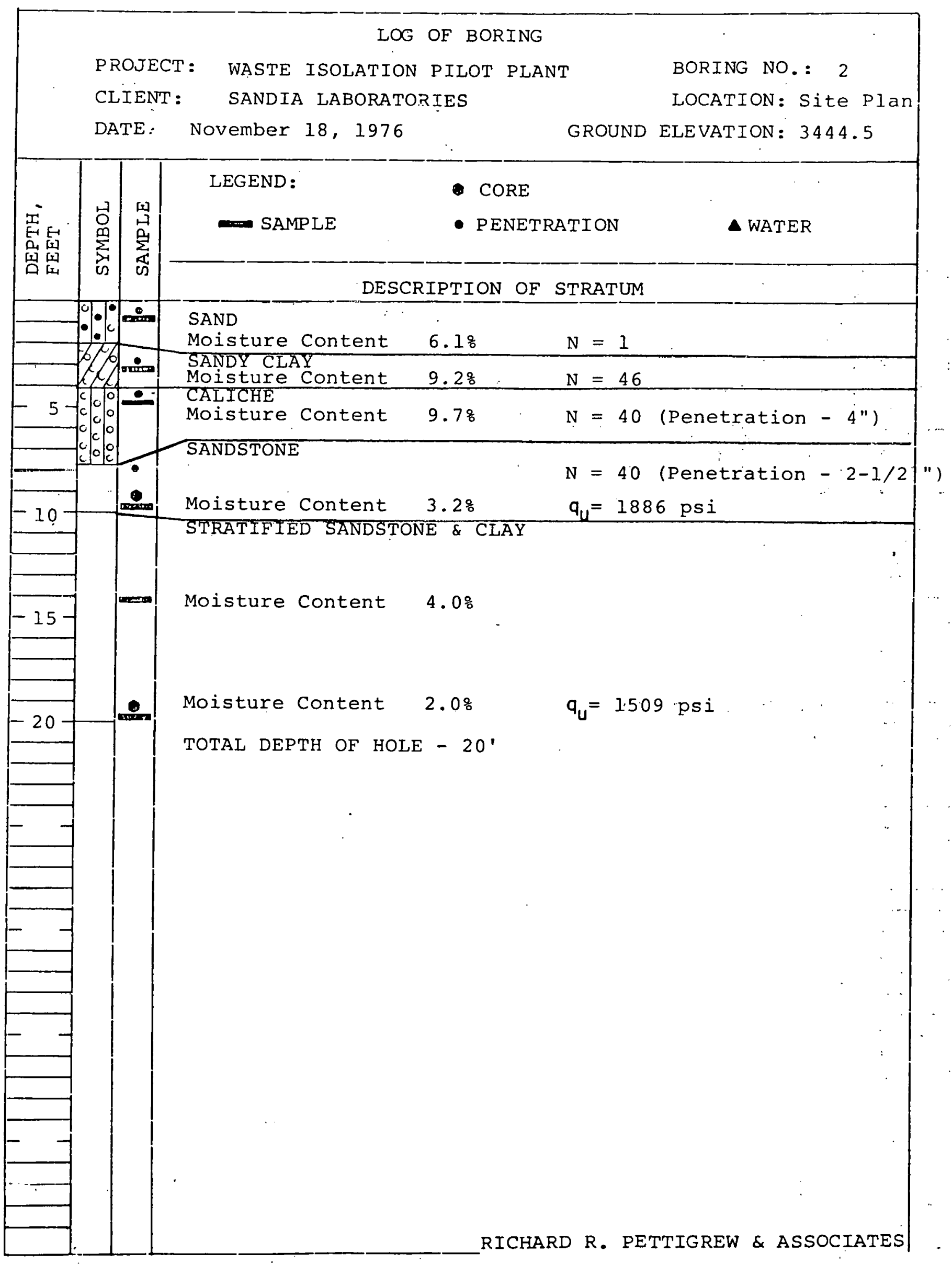




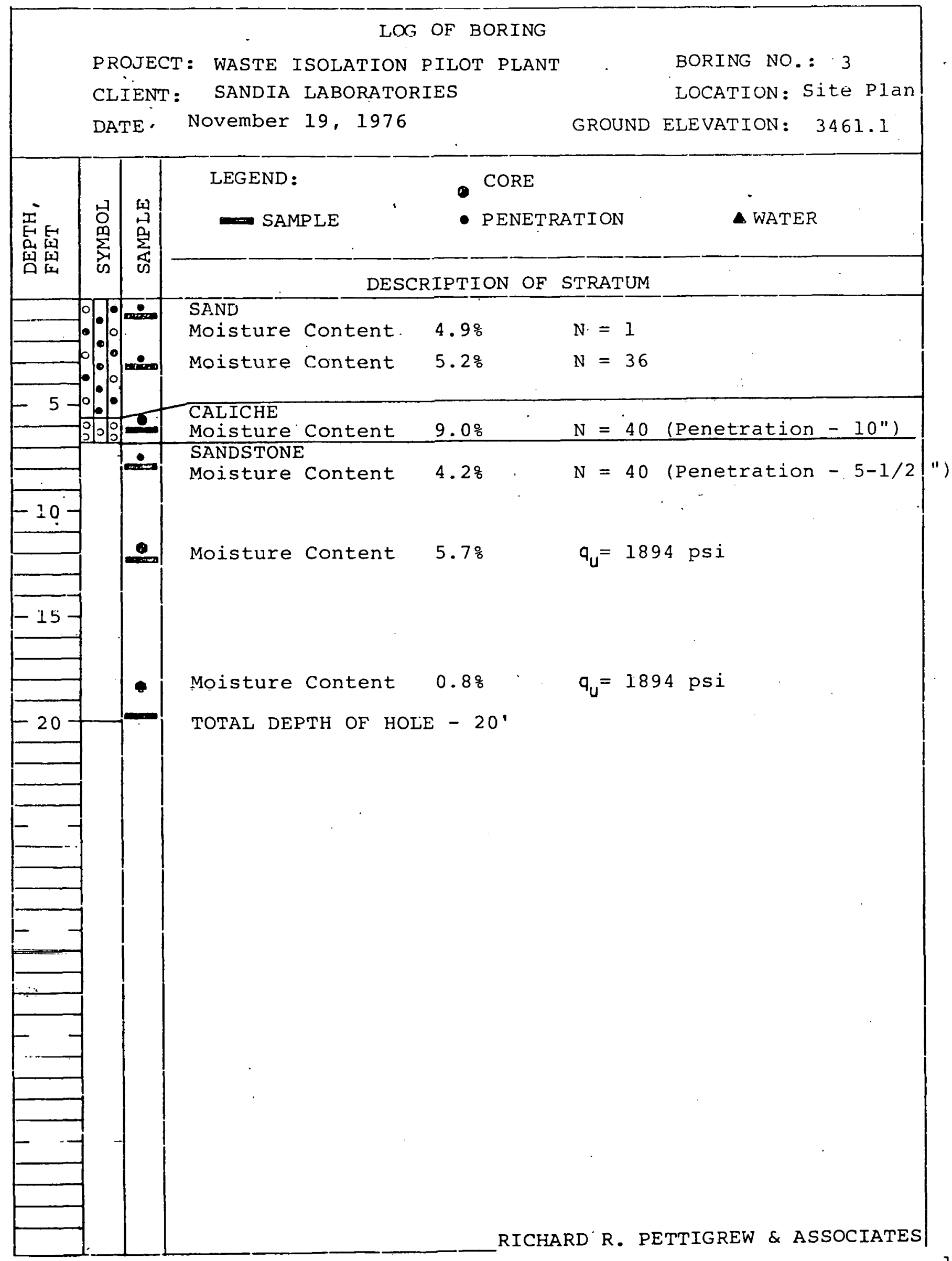




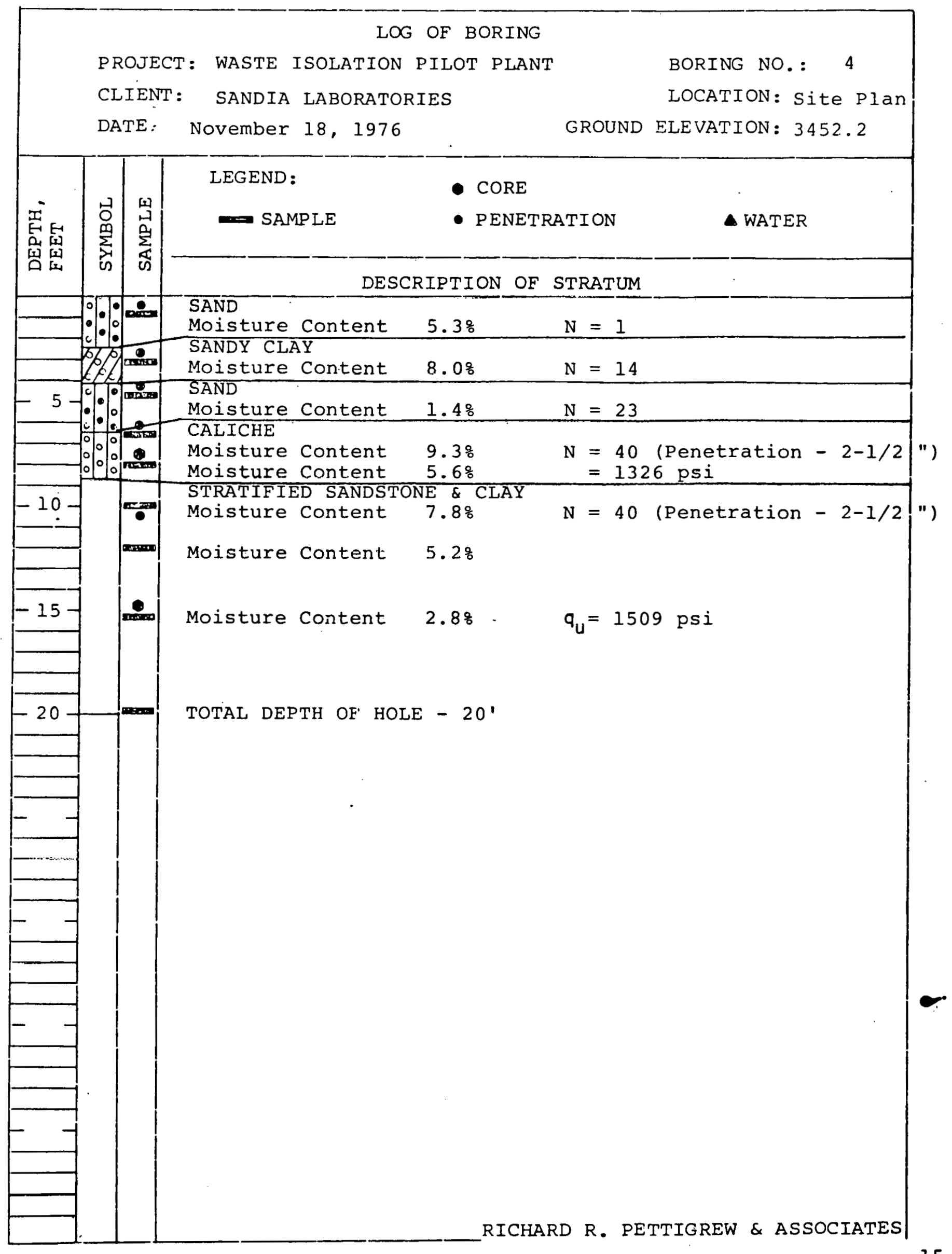




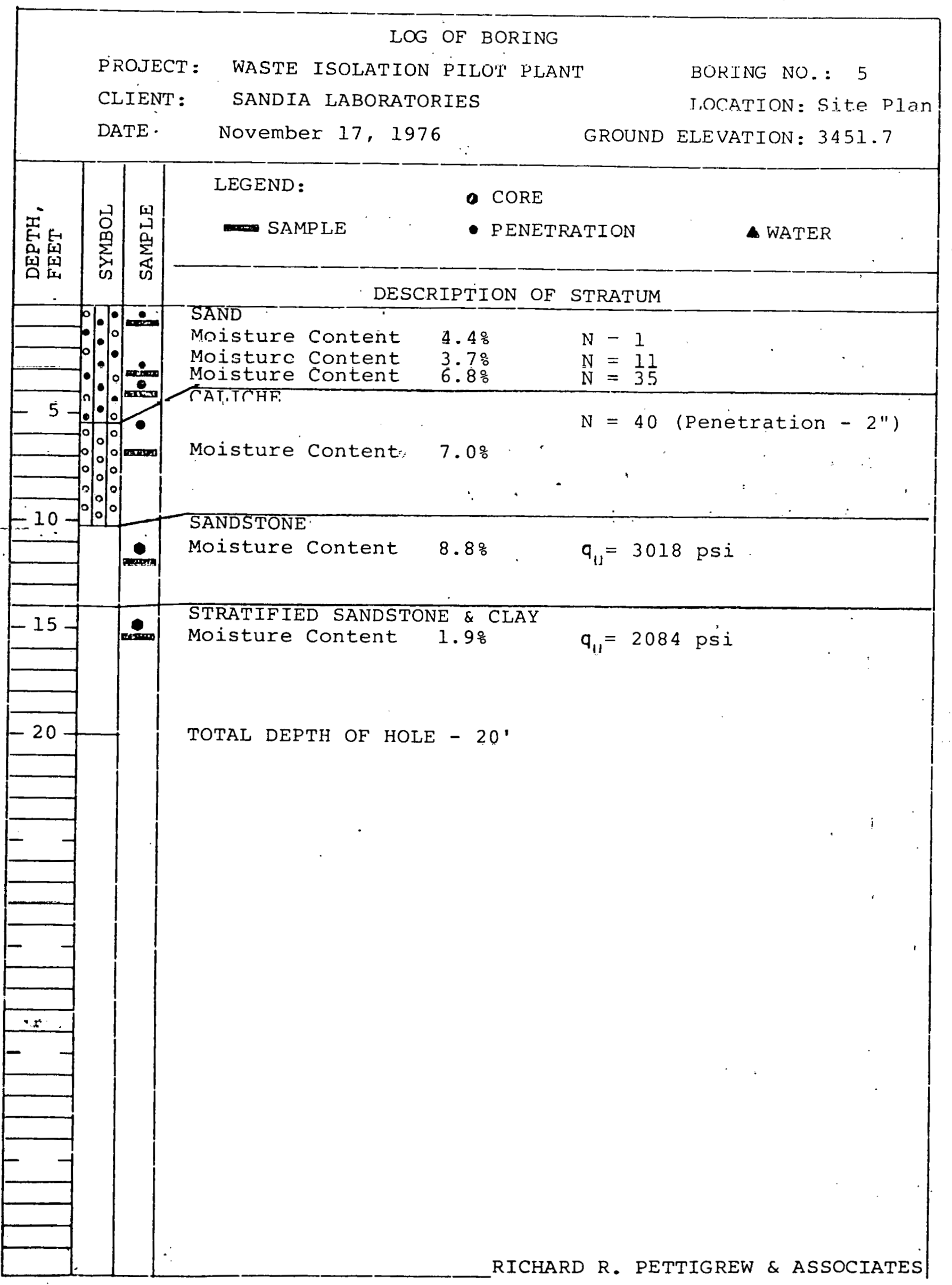




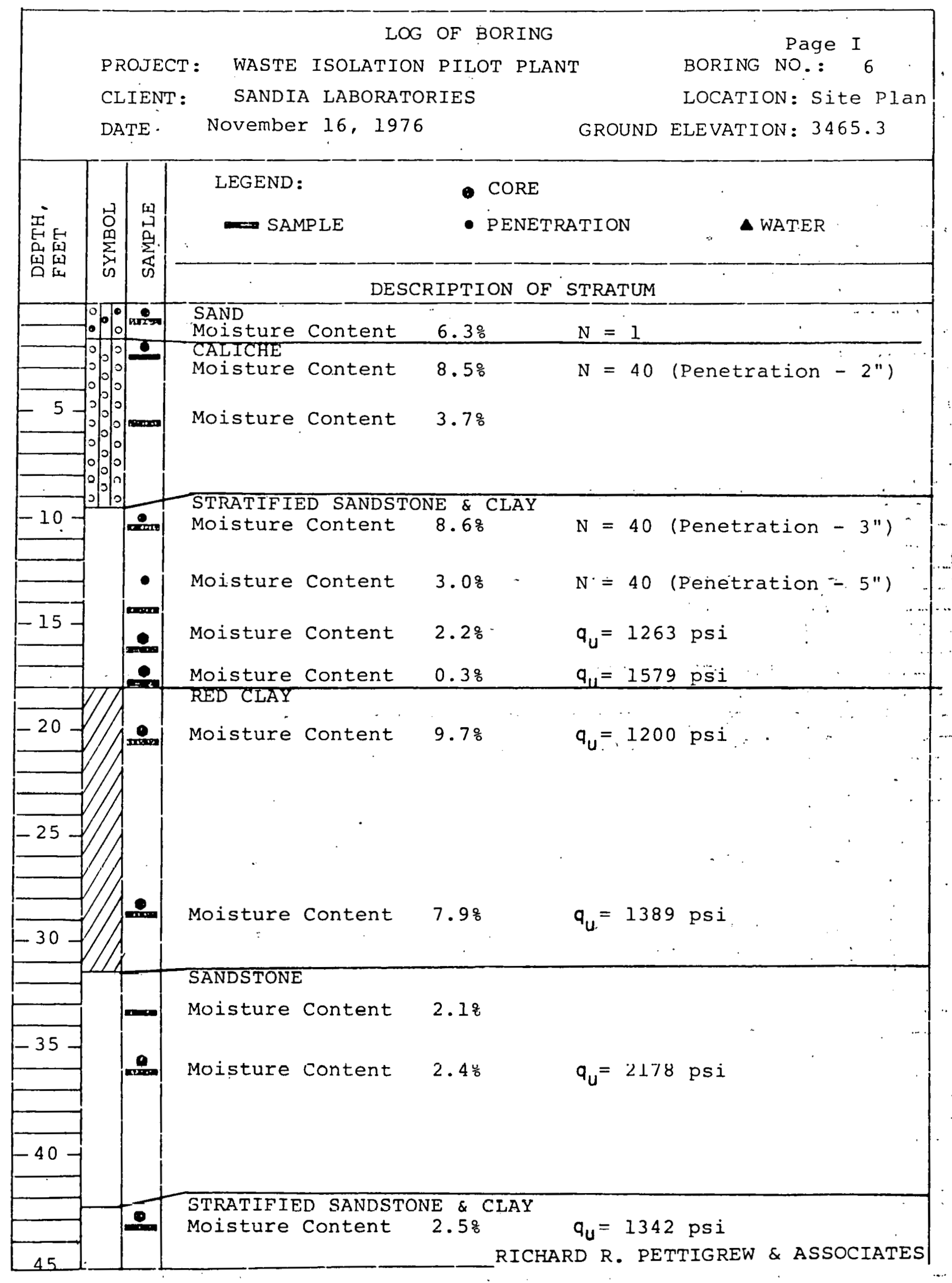




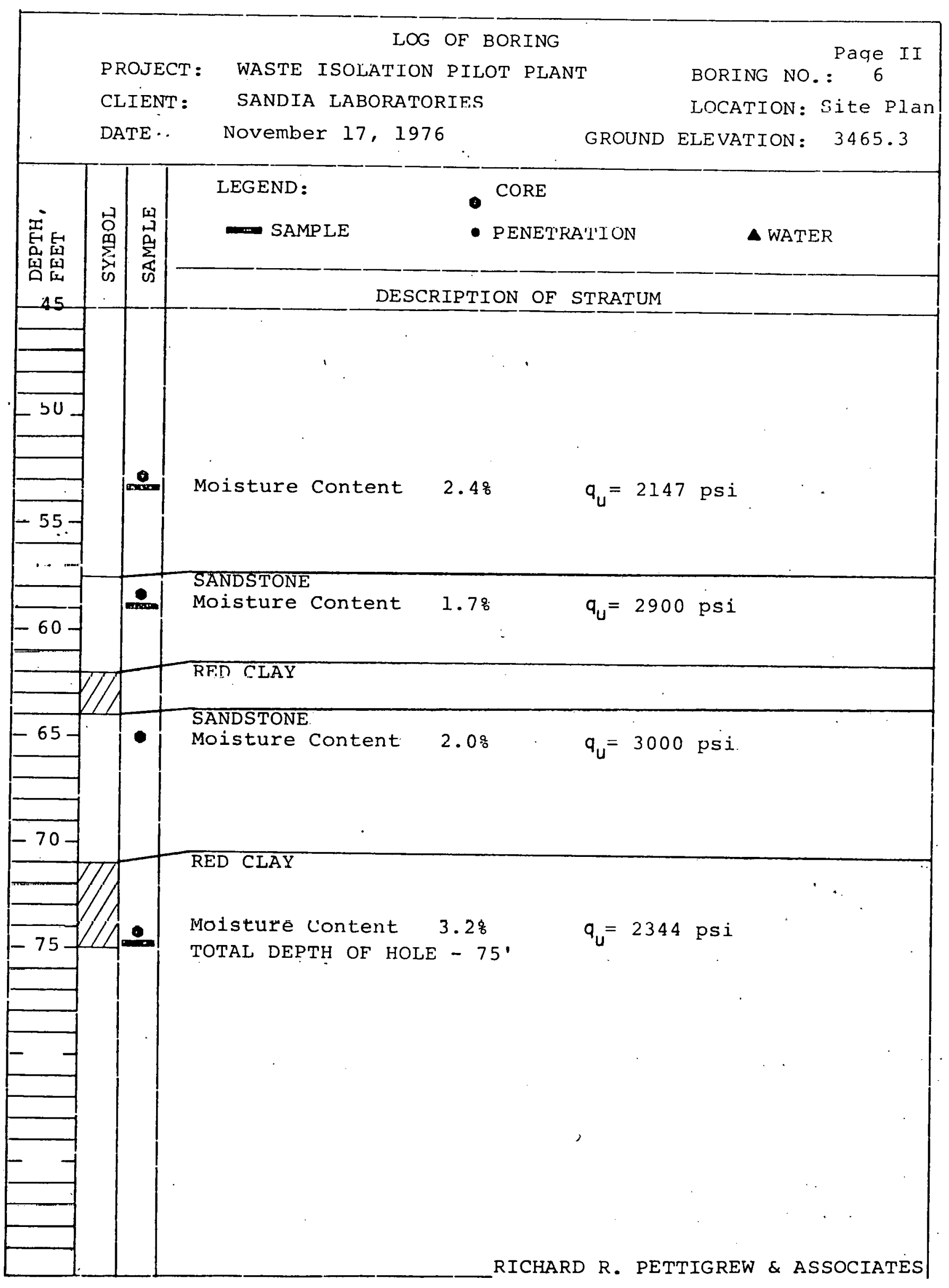




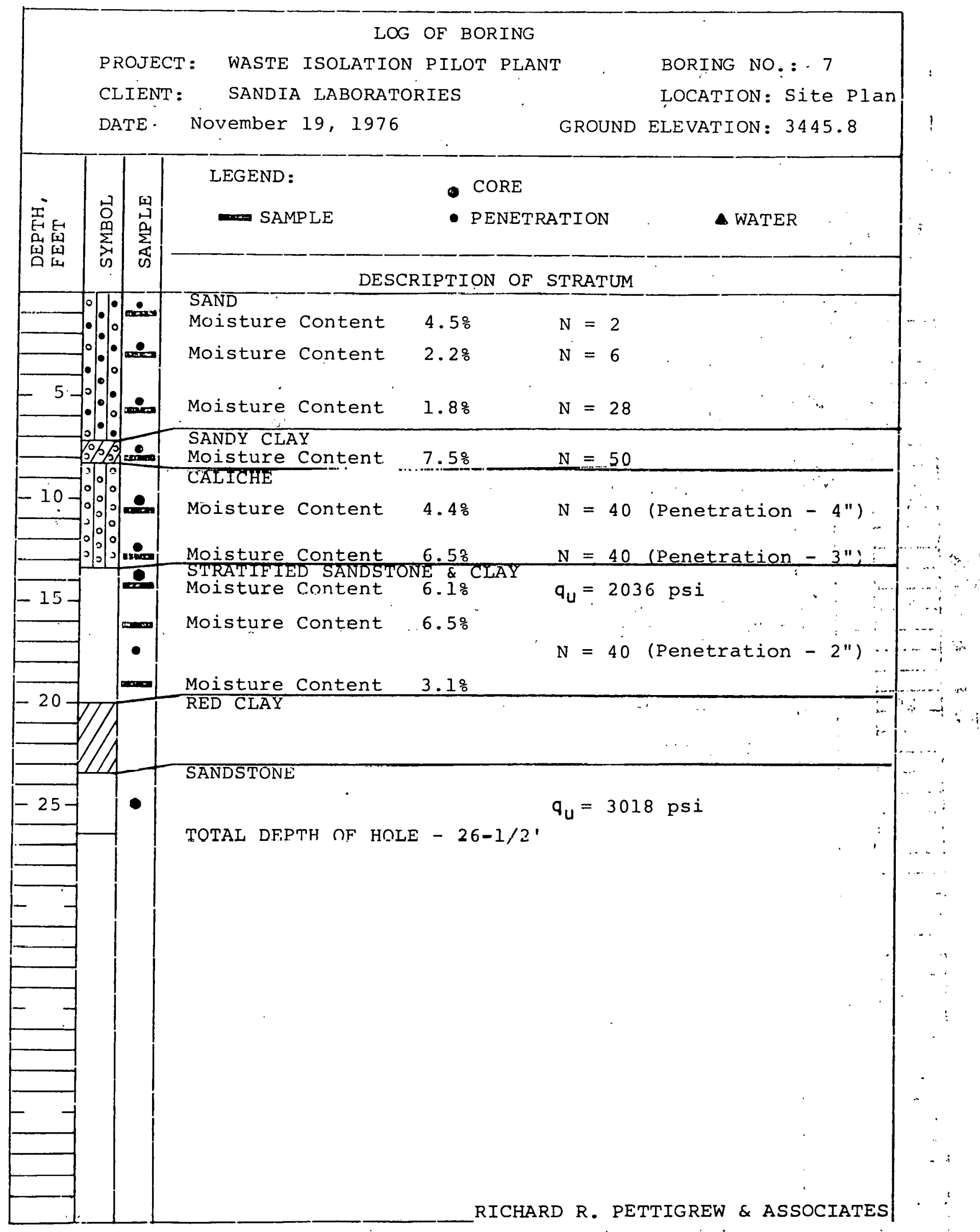




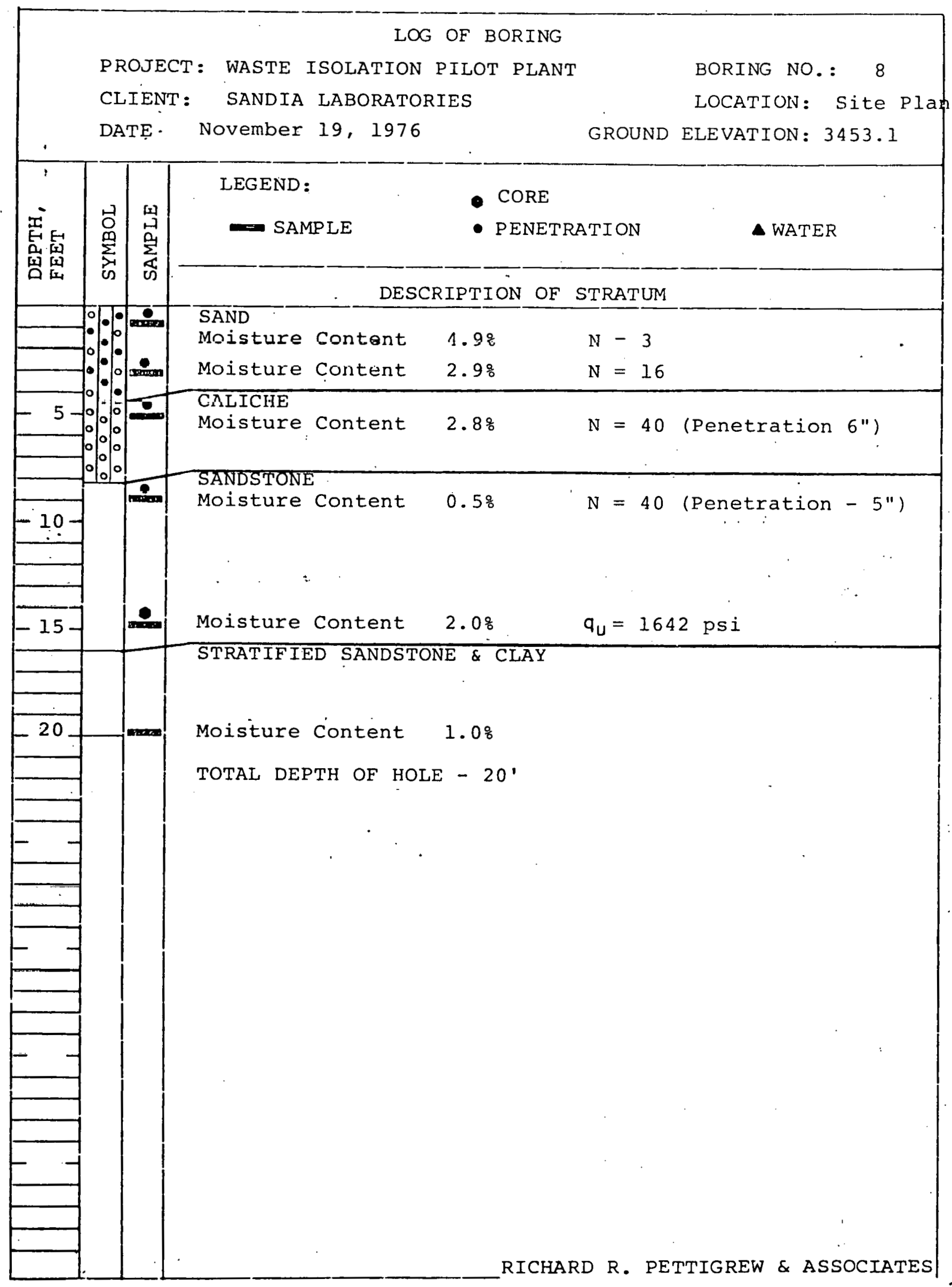




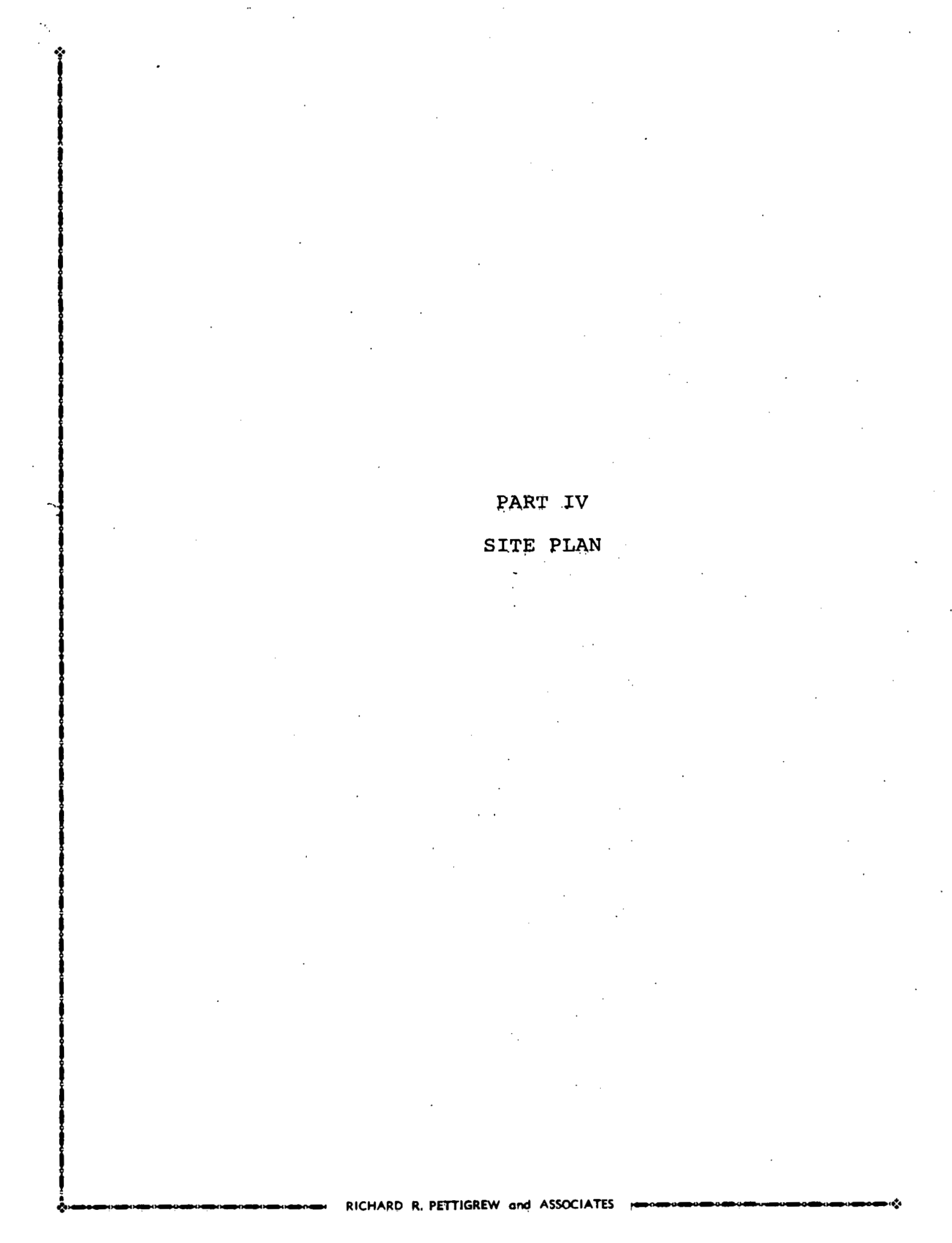


WIPP SOIL INVESTIGATION

REVISED DRILL HOLE LOCATIONS

SEC. 21, T22S, R31E, N.M.P.M.,

EODY COUNTY, NEW MEXICO

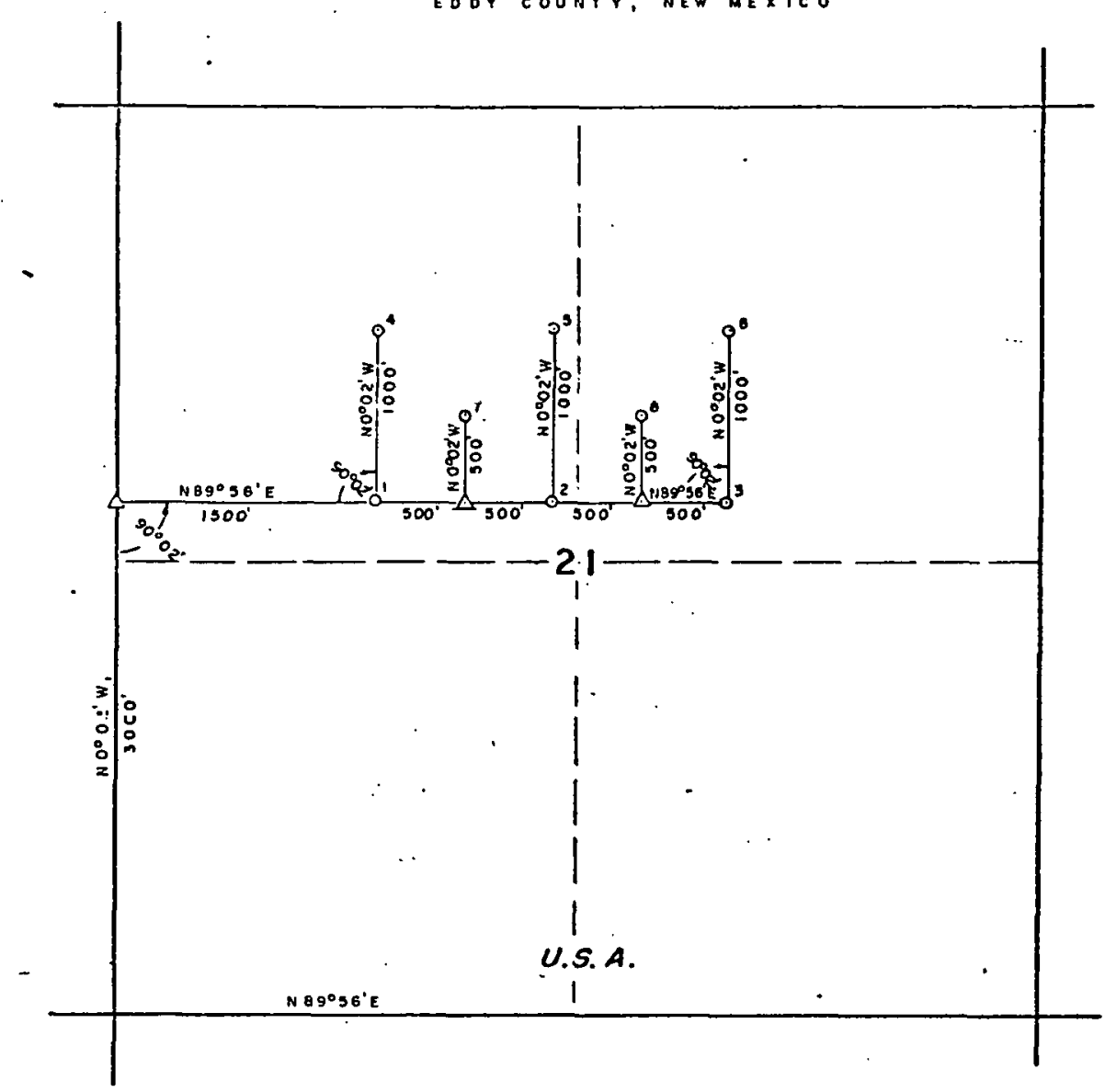

- INDICATES DRILL hOLE MARKED GY SB" IRON POD

$\triangle$ INDICATES TUANING HUa MAAED BY IRON NAIL

Surveyed: Oct. 6, 1976

iveather : Warm and clear

P. C. : N. King

Chain : B. Thompson

A. Mussett

\section{Elevations}

$\begin{array}{ll}\text { No. } 1 & 34.35 .42 \\ \text { No. } 2 & 3444.49 \\ \text { No. } 3 & 3461.06 \\ \text { No. } 4 & 3452.21 \\ \text { No. } 5 & 3451.68 \\ \text { No. } 6 & 3465.25 \\ \text { No. } 7 & 3445.76 \\ \text { No. } 8 & 3453.09\end{array}$

I HEREBY CERTIFY THAT THIS PLAT WAS MADE FPON HOTES TAMEN IN THE FIELO IN A BCNA FIDE SURVEY NADE UNOEA MY SUPERVISION. ANO THAT THE SAME IS TRUE AHO CORRECT TO THE BEST OF MY KNOWLEDGE ANO BELIEF.

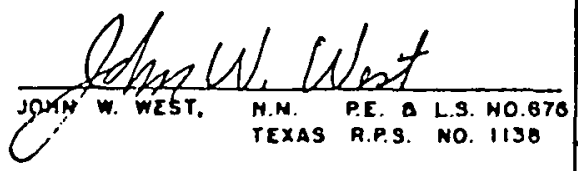

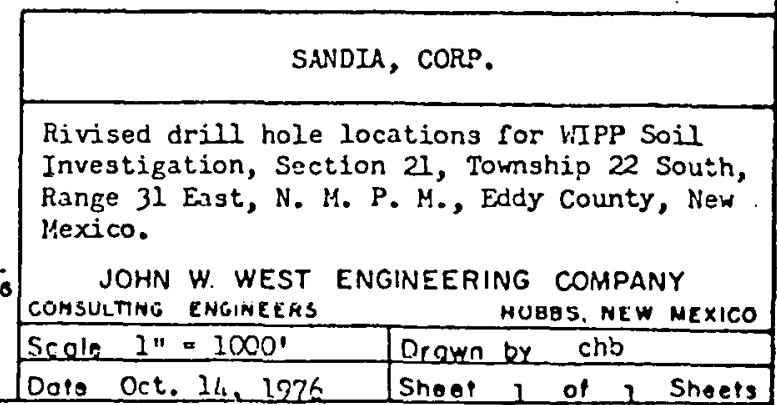




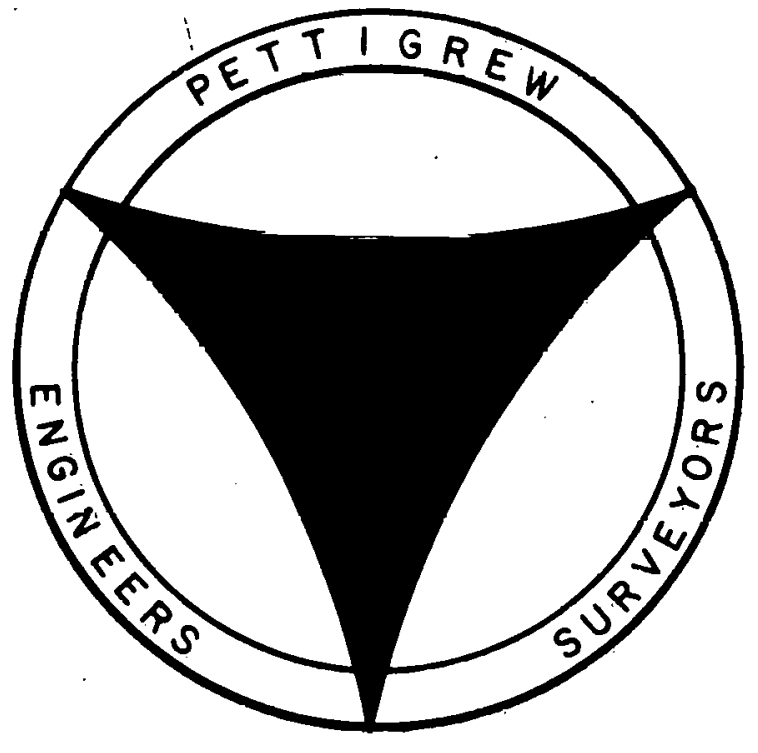

RICHARD R. PETTIGREW

AND ASSOCIATES

CONSULTING ENGINEERS

POST OFFICE DRAWER 807

613 INDUSTRIAL PARK

Clovis, New Mexico 88101

(505) 762.3716 